\title{
SISTEM PENGUKURAN KINERJA MENGGUNAKAN METODE PERFORMANCE PRISM DI PT KARUNG EMAS MANYAR GRESIK
}

\author{
Anik Rufaidah ${ }^{(1)}$ Mohamad Iqbal Vidianto(2) \\ 1,2 Program Studi Teknik Industri Sekolah Tinggi Teknik Qomaruddin Gresik \\ Jalan Raya No. Bungah Gesik 611512 - Indonesia \\ 1'Anik rufaidah99@gmail.com
}

\begin{abstract}
ABSTRAK
PT. Karung Emas adalah perusahaan penunjang bagi industri atau perusahaan lain dikarenakan karung adalah komponen utama dalam proses pengemasan hasil akhir suatu produk.Pengukuran kinerja sangat penting bagi perusahaan, dengan mengukur kinerja, perusahaan dapat melakukan analisa apakah perusahaan berjalan pada arah yang benar atau tidak dalam mencapai tujuan perusahaan. Dengan mengunakan metode Performance Pirsm dalam pengukuran kinerja pada PT Karung Emas sistem pengukuran kinerja menjadi terintergrasi dan komprehensif dimana dalam penentuan Key Performance indicator pada PT Karung Emas ini mengidentifikasi 5 sisi Performance Prism yaitu stakeholder kebutuhan, stakehoder konribusi, strategi, proses dan kapabilitas. Hasil peneitian menunjukan terdapat 24 $\mathrm{KPI}$ untuk kinerja kebutuhan stakeholder, $24 \mathrm{KPI}$ kontribusi stakeholder, $15 \mathrm{KPI}$ kinerja strategi, $15 \mathrm{KPI}$ kinerja proses, $15 \mathrm{KPI}$ kinerja kapabilitas. Terdapat lima KPI yang harus dilakukan perbaikan untuk meningkatkan kinerja perusahaan yaitu KPI kebutahan stakeholder dari konsumen, KPI kontribusi stakeholder dari investor, KPI strategi dari masayarakat, KPI proses dari konsumen dan KPI kapibiitas dari konsumen.
\end{abstract}

Kata Kunci : Pengukuran Kinerja, Performance Prism, Stakeholder, Key Performance Indicator.

\section{PENDAHULUAN}

Perkembangan industri di Indonesia yang semakin tinggi, menyebabkan persaingan perindustrian semakin ketat. Untuk menghadapi persaingan yang se makin ketat ini, setiap perusahaan dituntut untuk melakukan beberapa usaha agar mendapatkan performansi kerja dan layanan bagi konsumen yang semakin baik. Sehingga kondisi ini perusahaan akan memiliki daya saing untuk berkompetisi dengan lainya. PT Karung Emas adalah perusahaan penunjang bagi industri atau perusahaan lain dikarenakan karung adalah komponen utama dalam proses pengemasan hasil akhir suatu produk.

Begitu juga halnya dengan PT Karung Emas. Perusahaan ini senantiasa mengevalusai kinerja karyawanya. Dalam menilai kinerja perusahaan, pihak manajemen melakukan suatu pengukuran kinerja yang dinamakan SKI (Sistem Kinerja Individu), SKI ini disebar kepada setiap bagian untuk penilaian kinerja personal.
Penilaian ini akan diisi langsung oleh atasan dari setiap karyawan di setiap bagian. Dengan adanya SKI ini, kinerja dari setiap personal dapat terukur dengan baik, tetapi ada satu kelemahan yang terjadi yaitu belum adanya pengukuran kinerja tingkat korporasi yang dapat menilai performa perusahaan secara keseluruhan.

Untuk mengatasi hal ini, digunakan suatu pengukuran kinerja yang mengedepankan pentingnya menyelaraskan aspek perusahaan (stakeholder) secara keseluruhan ke dalam suatu framework pengukuran yang strategis. Stakeholder ini meliputi konsumen, distributor, investor, supplier, karyawan, masyarakat. Konsep pengukuran kinerja ini dikenal dengan istilah Performance Prism. Performance Prism merupakan salah satu pengukuran kinerja yang mempunyai lima sisi (facets) yang membentuk framework tiga dimensi berupa perisma segitiga. Sisi atas dan bawah merupakan stakeholder satisfaction dan 
stakeholder contribution. Sedangkan tiga sisi yang lain adalah strategies, processes, dan capabilities.

Performance Prism memberikan pengukuran yang komprehensif dan sudut pandang yang luas, sehingga memberikan gambaran yang realistis mengenai penentu kesuksesan bisnis. Selain itu. Prism tidak hanya mengukur hasil akhir, tetapi juga aktivitas-aktivitas penentu hasil akhir. Dengan demikian, pengukuran kinerja dapat memberikan gambaran yang jelas dan nyata tentang kondisi perusahaan yang sebenarnya. Performance Prism meliputi interaksi antara Stakeholder contribution dan Stakeholder satisfaction yang kemudian diproyeksikan kedalam strategy, process dan Capability. Dalam Performance Prism, identifikasi Key Performance Indicator (KPI) menjadi tolak ukur dalam pengukuran kinerja.

Metode Prism adalah pengukuran kinerja inovatif dan kerangka kerja menejemen kineja dengan memperhatikan beberapa sisi dari para stakeholder agar lebih maksimal. Kelebihannya dari kerangka kerja lainnya adalah bahwa Performance Prism meliputi semua stakeholder oerganisasi. Beberapa sisii Performance Prism adalah :

1. Stakeholder Stisfacition

2. Stakeholder Contribution

3. Strategi

4. Proses

5. kapabilitas

Key Performance Indicator (KPI) adalah suatu indikator yang menyajikan serangkaian ukuran yang fokus pada aspek-aspek kinerja organisasi yang palin penting untuk keberhasilan oerganisasi pada saat ini dan waktu yang akan datang

Adapun beberapa manfaat dari penetapan Key Performance Indicators dalam perusahaan adalah:

1. Dengan KPI maka kinerja perusahaan dan setiap individu dapat dievaluasi secara lebih objektif dan terukur, sehingga dapat mengurangi unsur subyektifitas yang sering terjadi dalam proses penilaian kinerja.

2. Melalui penentuan KPI secara tepat, setiap individu atau divisi dapat menjadi paham mengenai hasil kinerja yang diharapkan. Hal ini akan mendorong individu atau divisi dalam perusahaan untuk bekerja lebih optimal untuk mencapai target kerja yang telah ditetapkan.

3. Melalui penetapan KPI yang obyektif dan terukur, proses pembinaan kinerja individu dapat dilakukan lebih terbuka dan sistematis.

\section{METODE \\ Jenis Data}

Obyek penelitian dilakukan di PT. Karung Emas. Dimana data yang dibutuhkan adalah keterkaitan dengan visi misi, struktur organisasi, data yang terkait dengan 5 facet Prism Performance untuk mengidentifikasi Key Performance Indicator. Populasi dalam penelitian ini adalah merupakan seluruh karyawan PT. Karung Emas, Yang berjumlah 100 dan Sampel yang diteliti meliputi: Pemegam saham (investor), Pelanggan (customer), Karyawan (Employess), Pemasok (supplier) dan Masyarakat. Kemudian data tersebut dilakukan tahapan pengukuran kinerja

1. Mengidentifikasi stakeholder satisfaction dan stakeholder contribution yang dimiliki oleh perusahaan.

2. Menetapkan tujuan (objective).

3. Menyesuaikan strategi, proses, dan kapabilitas yang dimiliki oleh perusahaan dalam memenuhi objective.

4. Mendefinisikan measures yang digunakan untuk pencapaian objective tersebut.

5. Melakukan penilaian level tiap Key Performance Indicators (KPI)

6. Menyusun Performance Measurement Record Sheet

7. Hasil pengukuran

\section{Uji Validitas}

Cara yang digunakan dengan analisis item. Setiap nilai pada setiap butir pertanyaan dikorelasikan dengan nilai total seluruh butir pertanyaan untuk suatu variabel dengan menggunakan rumus korelasi product moment:

$$
r_{x y}=\frac{N \sum X Y-\left(\sum X\right)\left(\sum Y\right)}{\sqrt{\left[N \sum X^{2}-\left(\sum X\right)^{2}\right]\left[N \sum Y^{2}-\left(\sum Y\right)^{2}\right]}}
$$

Dimana:

$\mathrm{N}$ = Banyaknya responden

$\mathrm{X}=$ Skor pertanyaan

$\mathrm{Y}=$ Skor Total

$r_{x y}=$ koefisien korelasi antara variabel $\mathrm{X}$ dan variabel $\mathrm{Y}$. 
Nilai $r$ (koefisien korelasi) yang diperoleh kemudian dibandingkan dengan nilai $r$ pada tabel $r$ product moment. Jika nilai $r$ hitung $>r$ tabel, maka data dianggap valid. Pernyataan-pernyataan tersebut dapat dianggap valid bila memiliki konsistensi internal, yaitu mengukur aspek yang sama. Apabila dalam perhitungan ditemukan pernyataan yang tidak valid, kemungkinan pernyataan tersebut kurang baik susunan katanya atau kalimatnya karena kalimat yang kurang baik dapat menimbulkan penafsiran yang berbeda.

\section{Uji Reliabilitas}

Salah satu metode pengujian reliabilitas adalah dengan menggunakan metode cronbach's alpha. Standar yang digunakan dalam menentukan reliabel dan tidaknya suatu instrumen penelitian umumnya adalah perbandingan antara nilai $r$ hitung dengan $r$ tabel pada taraf kepercayaan tertentu. Apabila dilakukan pengujian reliabilitas dengan metode cronbach's alpha maka nilai $r$ hitung diwakili oleh nilai alpha. Apabila alpha hitung lebih besar daripada $r$ tabel dan alpha hitung bernilai positif, maka suatu instrumen penelitian dapat disebut reliabel (Budi, 2005).

Reliabilitas dapat dilakukan dengan menghitung koefisien cronbach's alpha. Rumus untuk menghitung koefisien cronbach's alpha adalah dengan persamaan:

$$
r_{11}=\frac{n}{n-1}\left(1-\frac{\sum \sigma_{i}^{2}}{\sigma_{t}^{2}}\right)
$$

Dimana:

$r_{11}=$ reliabilitas instrumen

$\mathrm{n}$ = banyaknya butiran pertanyaan atau banyaknya soal

$\sigma_{i}^{2}=$ jumlah varians skor tiap-tiap item

$\sigma_{t}^{2}=$ Varians total

\section{HASIL DAN PEMBAHASAN}

Pengumpulan data perusahaan melalui wawancara dan data internal perusahaan. Ini dilakukan untuk mengetahui jumlah karyawan di PT. Karung Emas. Adapun jumlah karyawan dan bagian-bagian ditunjukan pada Tabel 1. Berdasarkan hasil pengumpulan data maka dapat dilakukan pengukuran kinerja perusahaan dengan menggunakan metode Performance Prism, maka perusahaan perlu mengidentifikasi dan melakukan validasi pada KPI yang berhubungan dengan pihak stakeholder dan perspektif pada perusahaan. KPI-KPI yang telah divalidasi maka akan disusun dalam sebuah bentuk hierarki kinerja. Hierarki kinerja ini dikelompokkan berdasarkan stakeholder, dengan menggunakan kriteria ini maka akan dihasilkan lima jenis seperti ditunjukan pada Tabel 2.

Tabel 1. Sample Karyawan PT. Karung Mas

\begin{tabular}{ccc}
\hline No & Bagian (Departement) & Jumlah \\
\hline 1 & Direktur \& Dewan Komisaris & 6 \\
2 & Marketing & 4 \\
3 & Keuangan & 4 \\
4 & Penjualan & 6 \\
5 & Pajak & 2 \\
6 & Formen & 2 \\
7 & Mekanik & 4 \\
8 & Distributor dan Logistik & 4 \\
9 & Kepala mesin & 9 \\
10 & Gudang jadi & 7 \\
11 & Gudang bahan baku & 5 \\
12 & Gudang seperpat & 2 \\
13 & QC & 4 \\
14 & Produksi & 60 \\
15 & URT & 3 \\
16 & Security & 12 \\
Jumlah & & 100 Orang
\end{tabular}

Sumber : Pengambilan Data 
Tabel 2. Hiraki Kinerja Kebutuhan Stakeholder PT. Karung Emas

\begin{tabular}{lll}
\hline Stakeholder & \multicolumn{1}{c}{ Key performance indicators } & Bobot \\
\hline \multirow{5}{*}{ Investor } & KPI KE 1. Peningkatan keuntungan & 0,0105 \\
& KPI KE 2. Kemudahan mengontrol perkembangn usaha & 0,0107 \\
& KPI KE 3. Adanya pelaporan neraca rugi/laba yang transparan & 0,0107 \\
& KPI KE 4. Target produksi terpenuhi & 0,0111 \\
& KPI KE 5. Realisasi biaya operasional yang sesuai dengan anggaran & 0,0105 \\
& KPI KE 6. Transaksi pembelian mudah dilakukan & 0,0107 \\
Konsumen & KPI KE 7. Kualitas produk yang baik (tidak cacat) & 0,0107 \\
& KPI KE 8. Pelayanan konsumen yang baik & 0,0095 \\
& KPI KE 9. Tanggapan complain yang cepat & 0,0100 \\
& KPI KE 10. Adanya peningkatan pendapatan & 0,0105 \\
& KPI KE 11. Adanya SOP yang jelas untuk karyawan & 0,0104 \\
& KPI KE 12. Adanya peningktan dan perbikan fasilitas kerja & 0,0109 \\
Karyawan & KPI KE 13. Adanya jaminan sosial dan kesahatan & 0,0107 \\
& KPI KE 14. Adanya penghargaan atas prestasi & 0,0105 \\
& KPI KE 15. Adanya porogaram pelatihan keterampilan kerja & 0,0098 \\
& KPI KE 16. Suasana kerja yang nyaman & 0,0112 \\
& KPI KE 17. Adanya perlakuan adil dari pemimpin & 0,0111 \\
& KPI KE 18. Pembayaran tepat waktu & 0,0107 \\
& KPI KE 19. Lead time yang cukup antara pemesanan dan pengiriman & 0,0099 \\
supplier & barang & 0,0105 \\
& KPI KE 20. Kelangsungan kerjasama yang baik & 0,0105 \\
& KPI KE 21 Adanya toleransi terhadap barang cacat & \\
& KPI KE 22. Adanya program sosial keagamaan yang dilaksanakan & 0,0102 \\
KPI KE 23. Ikut mengembangkan usaha kecil di daerah sekitar & 0,0109 \\
& KPI KE 24. Adanya bantuan untuk masyrakat & 0,0105 \\
\hline \multirow{5}{*}{ Masyarakat }
\end{tabular}

Sumber : Hasil Analisa Data (2017)

Tabel 3. Hiraki Kinerja Kontribusi Stakeholder PT. Karung Emas

\begin{tabular}{|c|c|c|}
\hline Stakeholder & Key performance indicators & Bobot \\
\hline \multirow{5}{*}{ Investor } & KPI KO 1. Menyediakan modal & 0,0108 \\
\hline & KPI KO 2. Memperhatikan perkembangan usaha & 0,0098 \\
\hline & KPI KO 3. Melakukan kontrol yang intensif terhadap keungan perusahaan & 0,0109 \\
\hline & KPI KO 4. Menyediakan lapangan kerja & 0,0103 \\
\hline & KPI KO 5. Menggunakan biaya oprasional dengan baik & 0,0103 \\
\hline \multirow{4}{*}{ Konsumen } & KPI KO 6. Memberikan keuntungan berupa profit bagi perusahaan & 0,0107 \\
\hline & KPI KO 7. Memberikan kepercayaan akan kualitas produk yang dijual & 0,0104 \\
\hline & KPI KO 8. Memberkan saran dan masukan kepada perusahaan & 0,0101 \\
\hline & $\begin{array}{l}\text { KPI KO 9. Adanya jaminan barang untuk dikembalikan sesuai } \\
\text { kesepakatan }\end{array}$ & 0,0102 \\
\hline \multirow{8}{*}{ Karyawan } & KPI KO 10. Karyawan mampu meningkatkan motivasi kerja & $0 ., 0103$ \\
\hline & KPI KO 11. Krayawan bekerja sesuai dengan SOP yang diberikan & 0,0110 \\
\hline & KPI KO 12. Berkosentarasi dalam melakukan pekerjaan & 0,0100 \\
\hline & KPI KO 13. Menghindari penyimpangan kerja & 0,0107 \\
\hline & KPI KO 14. Mengoptimalkan setiap aktivitas yang dikerjakan & 0,0108 \\
\hline & KPI KO 15. Karyawan mengikuti pelatihan keterampilan kerja dengan & 0,0102 \\
\hline & baik & 0,0103 \\
\hline & $\begin{array}{l}\text { KPI KO 16. ikut Karyawan merawat fasilitas perusahaan dengan baik } \\
\text { KPI KO 17. Tidak sungkan untuk memberikan saran kepada pemimpin }\end{array}$ & 0,0109 \\
\hline \multirow{4}{*}{ Supplier } & KPI KO 18. Melakukan pengiriman tepat waktu & 0,0108 \\
\hline & KPI KO 19. Melakukan pengiriman sesuai kesepakatan & 0,0106 \\
\hline & KPI KO 20. Memberikan kemudahan pemesanan & 0,0101 \\
\hline & KPI KO 21. Memberikan garansi & 0,0103 \\
\hline \multirow{3}{*}{ Masyarakat } & KPI KO 22. Berpartisipasi dalam program dari perusahaan & 0,0104 \\
\hline & KPI KO 23. Mengikuti program keterampilan yang diadakan perusahaan & 0,0108 \\
\hline & $\begin{array}{l}\text { KPI KO 24. Memanfaatkan program dari perusahaan dengan sebaik-baik } \\
\text { nya }\end{array}$ & 0,0104 \\
\hline
\end{tabular}

Sumber : Hasil Analisa Data (2017) 
Tabel 4. Hiraki Kinerja Strategi Stakeholder PT. Karung Emas

\begin{tabular}{clc}
\hline Stakeholder & \multicolumn{1}{c}{ Key performance indicators } & Bobot \\
\hline \multirow{5}{*}{ Investor } & KPI S 1. Index pengeluaran modal & 0,0106 \\
& KPI S 2. Tingkat perkembangan bisnis & 0,0121 \\
& KPI S 3. Pemanfaatan aset perusahaan secara optimal & 0,0119 \\
& KPI S 4. Biaya yang baik & 0,0113 \\
& KPI S 5. Pertambahan pelanggan & 0,0117 \\
\multirow{5}{*}{ Konsumen } & KPI S 6. Index kepuasan pelangan & 0,0117 \\
& KPI S 7. Index pengembangan prodak dan pelayanan & 0,0119 \\
& KPI S 8. Perbaikan kondisi kerja perusahaan & 0,0114 \\
\multirow{5}{*}{ Karyawan } & KPI S 9. Tingkat produktivitas karyawan & 0,0120 \\
& KPI S 10. Tingkat hubunngan karyawaan yang unggul & 0,0118 \\
\multirow{2}{*}{ Supplier } & KPI S 11. Kebijakan kesehatan kerja & 0,0110 \\
& KPI S 12. Pengontrolan kerja supllair & 0,0113 \\
& KPI S 13. Menjaga komunikasi dengan supplier & 0,0119 \\
& KPI S 14. Tingkat aktivitas sosial & 0,0116 \\
& KPI S 15. Pengenalan lebih dalam mengenai masyarakat & 0,0105 \\
\hline
\end{tabular}
Sumber : Hasil Analisa Data (2017)

Tabel 5. Hiraki Kinerja Proses Stakeholder PT. Karung Emas

\begin{tabular}{|c|c|c|}
\hline Stakeholder & Key performance indicators & Bobot \\
\hline \multirow{4}{*}{ Investor } & KPI P 1. Perencanaan investor & 0,0116 \\
\hline & KPI P 2. Jumlah permintaan produk karung di pasaran & 0,0120 \\
\hline & KPI P 3. Ketelitian penagana inforfasi data yang telitu & 0,0116 \\
\hline & KPI P 4. Hasil investasi pengembangan prodak & 0,0192 \\
\hline & KPI P 5. Memberikan diskon khusus & 0,0107 \\
\hline \multirow{2}{*}{ Konsumen } & KPI P 6. Penanganan keluhan yang cepat & 0,0083 \\
\hline & KPI P 7. Tingkat pembuatan karung dengan sepesifikasi yang baru & 0,0116 \\
\hline \multirow{4}{*}{ Karyawan } & KPI P 8. Penindakan terhadap pelanggaran kerja & 0,0107 \\
\hline & KPI P 9. Tingkat kinerja karyawan & 0,0113 \\
\hline & KPI P 10. Komunkasi antara atasan dan bawahan yang baik & 0,0114 \\
\hline & KPI P 11. Adanya jaminan pengobtan untuk karyawan & 0,0116 \\
\hline \multirow[b]{2}{*}{ Supplier } & KPI P 12. Membuat kesepakatan dengan supplier tentang standar & 0,0114 \\
\hline & $\begin{array}{l}\text { mutu prodok } \\
\text { KPI P 13. Koordinasi bagian pembelian dengan supplier }\end{array}$ & 0,0102 \\
\hline \multirow{2}{*}{ Masyarakat } & KPI P 14. Pegembangan CSR & 0,0118 \\
\hline & Frekuensi pertemuan dengan masayarakat sekitar & 0,0106 \\
\hline
\end{tabular}

Sumber : Hasil Analisa Data (2017)

Tabel 6. Hiraki Kinerja Kapabilitas Stakeholder PT. Karung Emas

KPI yang Perlu Usulan Perbaikan

Diperbaiki

KPI Kebutuhan 8 1. Dilakukan perbaikan dengan konsep Supply Chain Management (SCM).

(konsumen)

( Pelayanan

konsumen yang baik ) Konsep ini diterapkan untuk perbaikan rantai pasokan dari perusahhan kepada intermediate customer yang dalam hal ini ini adalah distributor. Perbaikan rantai pasokan ini dapat dilakukan dengan beberapa cara antara lain perbaikan pola distribusi yang ada, diharapkan dapat meningkatkan pelayanan terhadap pelanggan.

KPI Kontribusi 2 1. Melakukan penelitian dan membuat suatu indikator perkembagan (investor)

( Memperhatiakan perkembangan usaha)

perusahaan secara berkala

2. Perusahaan sering membagikan kuesioner terhadap stakeholder yang berhubugan dan penilaian mengenai kinerja perusahaan

KPI Strategi 15

(masyarakat)

( Pengenalan lebih

dalam mengenai masyarakat)
1. Melakukan survey kepuasan masyarakat

2. Masyarakat sebisa mungkin dilibatkan dalam acara yang di selengarakan oleh perusahaan sehingga masyarakat merasa di perhatikan

Sumber : Hasil Analisa Data (2017) 
Tabel 7. Hiraki Kinerja Kapabilitas Stakeholder PT. Karung Emas (Lanjutan)

\begin{tabular}{|c|c|c|c|}
\hline \multicolumn{2}{|c|}{ KPI yang Perlu Diperbaiki } & \multicolumn{2}{|l|}{ Usulan Perbaikan } \\
\hline \multirow{2}{*}{\multicolumn{2}{|c|}{$\begin{array}{l}\text { KPI Poroses } 6 \\
\text { (konsumen) } \\
\text { ( Penaganan keluhan } \\
\text { yang cepat) }\end{array}$}} & \multicolumn{2}{|c|}{$\begin{array}{l}\text { 1. Membuat call center bebas pulsa yang dapat menampung seluruh } \\
\text { saran dari konsumen }\end{array}$} \\
\hline & & \multicolumn{2}{|c|}{$\begin{array}{l}\text { 2. Melakukan pertemuan atau kegitan sosial bersama dengan beber } \\
\text { pihak pelanggan }\end{array}$} \\
\hline \multirow{2}{*}{\multicolumn{2}{|c|}{$\begin{array}{c}\text { KPI Kapibilitas } 5 \\
\text { (konsumen) } \\
\text { (Perluasan promosi ) }\end{array}$}} & \multirow{2}{*}{\multicolumn{2}{|c|}{$\begin{array}{l}\text { 1. Melakukan kerjasama usaha dengan para kelompok tani da } \\
\text { pemerintah untuk pengenalan produk. } \\
\text { 2. Menjadi sponsor dalam acara-acara besar sehingga dapat } \\
\text { meningkatkan nilai produk dari perusahaan }\end{array}$}} \\
\hline & & & \\
\hline \multicolumn{4}{|c|}{ Sumber : Hasil Analisa Data (2017) } \\
\hline \multicolumn{4}{|c|}{ Tabel 8. Hasil Perbaikan KPI } \\
\hline Stakeholder & & Key performance indicators & Bobot \\
\hline \multirow{4}{*}{ Investor } & $\mathrm{KPI} \mathrm{KP} 1$ & . Data keungan & 0,0113 \\
\hline & $\mathrm{KPI} \mathrm{KP} 2$ & Perhitungan resiko investasi & 0,0103 \\
\hline & $\mathrm{KPI} \mathrm{KP} 3$ & Sistem informasi yang terpercaya & 0,0105 \\
\hline & KPI KP 4 & Investor menjadi salah satu direksi & 0,0110 \\
\hline \multirow{4}{*}{ Konsumen } & KPI KP 5 & Perluasan promosi & 0,0098 \\
\hline & KPI KP 6 & Adanya layanan keluhan & 0,0106 \\
\hline & KPI KP 7 & Penentuan kualitas & 0,0106 \\
\hline & KPI KP \& & Kebijakan penerimaan keluhan karyawan & 0,0104 \\
\hline \multirow{3}{*}{ Karyawan } & KPI KP $\mathrm{C}$ & Tingkat pelatihan yang dilakukan & 0,0107 \\
\hline & KPI KP 1 & 0 . Perkembangan gaji disetiap tingkat & 0,0116 \\
\hline & KPI KP 1 & 1. Berkerjasama dengan tenaga medis & 0,0103 \\
\hline \multirow{2}{*}{ Supplier } & KPI KP 1 & 2. Informasi kinerja supplier yang dipercaya & 0,0102 \\
\hline & KPI KP 1 & 3. Pengecekan kualitas pada produk pesana & 0,0103 \\
\hline \multirow[b]{2}{*}{ Masyarakat } & KPI KP 1 & 4. Tingkat pelatihan terhadap sumber daya lokal & 0,0115 \\
\hline & KPI KP 1 & 5. Donasi sosial yang diberikan kepada masyarakat & 0,0105 \\
\hline
\end{tabular}

Sumber : Hasil Analisa Data (2017)

Dari Hasil pembobotan masing-masing perspektif diatas, langkah selanjutnya dilakukan perbaikan kinerja perusahaan melalui KPI dengan nilai bobot terendah dengan memberikan usulan perbaikan dimana KPI kebutuhan stakeholder dari konsumen yaitu adanya pelayanan konsumen yang baik, KPI kontribusi stakeholder dari investor yaitu memperhatikan perkembangan usaha, KPI strategi dari masyarakat yaitu pengenalan lebih dalam mengena masyarakat, KPI proses dari konsumen penaganan keluhan yang cepat dan KPI kapibiitas dari konsumen perluasan promosi seperti pada Tabel 8.

\section{KESIMPULAN.}

Kinerja perusahaan secara keseluruhan sudah sesuai dengan harapan yang dinginkan oleh PT. Karung Emas, terdapat 24 KPI untuk kinerja kebutuhan stakeholder, $24 \mathrm{KPI}$ kontribusi stakeholder,
$15 \mathrm{KPI}$ kinerja strategi, $15 \mathrm{KPI}$ kinerja proses, $15 \mathrm{KPI}$ kinerja kapabilitas dan terdapat lima KPI yang harus dilakukan perbaikan guna meningkatkan kinerja perusahaan.

\section{DAFTAR PUSTAKA}

Armstrong, Michael, 2004. Performance Management. Tugu. Jogjakarta

Bastian, Indra. 2006. Akuntansi Sektor Publik.Jakarta: Erlangga.

Dania, Wike Agustin Prima. 2012. Analisis Pengukuran Korporasi Menggunakan Metode Performance Prism. Malang: Jurnal Teknologi Pertanian. Vol. 13. No. 1:67-77

Firdaus, Dzulchis. 2014. Pengukuran Kinerja Perusahaan Menggunakan Balance Scorecard. Surabaya: Jurnal IImu dan Riset Akuntansi. Vo.3 No.8 
Insukindrodan, A. 1999. Pemilihan dan Fungsi Empirik: Studi Kasus Perminatan Uang Kartal Riil di Indonesia. Jakarta: Jurnal Ekonomi dan Bisnis Indonesia. Vol. 14,No. $4: 49-61$.

Kuncoro, Mudrajad. 2005. Strategi Bagaimana Meraih Keunggulan Kompetiti. Jakarta: Erlangga.

Kusuma, Welin. at all. 2006. Perancangan dan Pengukuran Kinerja dengan Menggunakan Metode Performance Prism di PT. Kangsen Kenko Indonesia Cabang Surabaya.
Surabaya: Prosiding Seminar Nasional Manajemen Teknologi III

Mardiasmo. 2009. Akuntansi Sektor Publik. Yogyakarta: Penerbit Andi.

Mulyadi. 2007.Sistem Akuntansi, Jakarta :Selemba Empat.

Moeheriono. 2012. Pengukuran Kinerja Berbasis Kompetensi. Jakarta: Raja Grafindo Persada

Neely, A.D., and Adams, C.A. 2000. Perpectives on Performances: The Performance Prism, Centre for Business Performance, Cranfield School of Management, UK. 